\title{
Resenha \\ Il Diritto Globale: giustizia e democrazia oltre lo stato (Sabino Cassese) ${ }^{1}$
}

\author{
Maurizio Oliviero \\ Márcio Ricardo Staffen
}

Sabino Cassese, juiz constitucional, professor na Escola Normal Superior de Pisa, na qual leciona História e Teoria do Estado, professor de Direito Administrativo global no mestrado de Negócios Públicos, no Instituto de Estudos Políticos de Paris, doutor honoris causa nas universidades de Aix-en-Provence, Cordoba, Paris, Atenas, Castilla-La Mancha e de Macerata, apresenta seu livro que suscita alguns questionamentos, a saber: em qual função estão os poderes públicos estatais e a globalização jurídica? O fenômeno da globalização ataca componentes fundamentais do Estado Moderno? É possível transportar democracia e justiça sobre o Estado?

Ainda que o fenômeno da globalização não se mostre uma novidade, certamente, a crise econômica vivida em 2008 demonstrou substancialmente os diversos níveis de marcha desse processo de expansão. Notadamente, a economia se globaliza com maior velocidade em comparação com a política (e com os assuntos do Estado), criando, neste panorama, assimetrias entre economia global (transnacional) e a política nacional (não se descartando a política comunitária). Evidenciou-se, sem exageros, a existência de uma governança global sem governo.

\footnotetext{
${ }^{1}$ Recebido em: 20/12/2012. Revisado em: 18/02/2013. Aprovado em: 10/03/2013.
} 
A partir dessas conjunturas, Sabino Cassese passa a responder aos questionamentos formulados. Defende o constitucionalista italiano a existência de uma ordem jurídica global, defesa essa que faz argumentando em torno de diversos elementos comprobatórios, como: plurissubjetividade, normatização, administração, jurisdição, legitimação e justiça.

Todavia, a existência de um direito global alimenta, nesta quadra da história, uma pluralidade de desafios, a iniciar pelas próprias bases de globalização, múltipla em sua essencial. Ao passo que a globalização guarda vastidão de caráteres, tais signos são observados também nos ordenamentos jurídicos, nacionais e internacionais. Há um forte problema decorrente do conflito entre uniformidade global e diferenças nacionais (locais), da concorrência entre normas globais, normas nacionais e normas locais, da identificação do juiz competente para conhecer/decidir sobre a pretensão resistida, seja ela nacional ou global. Cite-se, a título de ilustração, o caso Massachusetts versus Environmental Protection Agency (n. 05-1120/2007), no qual a Suprema Corte americana decidiu pela impossibilidade de tutela jurisdicional em razão de problemas de legitimidade e capacidade de dimensionar o dano ambiental diante do caráter difuso do bem jurídico.

No intuito de explanar sobre o direito global, Cassese estuda o modo pelo qual o direito e seus princípios têm ganhado espaço na ordem global. A partir de dez cases, ele constata a adoção de princípios básicos de utilização e construção do direito global, a saber: o devido processo legal, a racionalidade, a proporcionalidade, o dever de motivação das decisões (inclusive, administrativas) e a justiça.

Em complemento, ele constata que: a) esta ordem jurídica global baseia-se em normas setoriais, relativas às matérias singulares ao caso; b) há um vazio hierárquico no ordenamento global (composto de normas transnacionais, supranacionais, nacionais e regionais); c) não existe uma uniformidade no ordenamento global; d) carece de um marco divisor entre o público e o privado; e) poder normativo e poder executivo necessitam estar separados; f) disposições contratuais gozam da mesma relevância dos atos normativos ou administrativos; $g$ ) a ordem jurídica global não se presta somente aos sujeitos de Direito Público; $h$ ) o dever 
de observância do rule of law; i) a possibilidade de disputas multipolares, inclusive com órgão jurisdicional intervindo e reexaminado decisões judicias nacionais; $j$ ) a compreensão de um ordenamento voltado prioritariamente à resolução de controvérsias; $k$ ) a diversidade de órgãos globais, que transcendem a pertinência aos sujeitos de Direito Internacional; l) a penetração do ordenamento global no Direito nacional, e $m$ ) a ausência de caráter vinculante, baseado, sim, na adesão voluntária.

Sabino Cassese analisa, também, a partir da constatação da penetração do ordenamento global na ordem jurídica nacional, a função dos juízes no espaço global-nacional. Função esta, proposta por Cassese, paralela à integração entre os diversos regimes regulatórios, em prol de constituir unidade entre tais ordenamentos plurais e distintos.

Por fim, ele aborda a problemática inerente à legitimação das instituições globais. Toca, nesse ponto, a construção, se possível, de uma democracia cosmopolita, capaz de influenciar a produção, a interpretação e a aplicação do ordenamento global. Nesse ínterim, posiciona-se no sentido de que a inexistência de instituição global eleita pelo voto popular não pode ser considerada expressão de um déficit democrático, para tanto, traz à baila o princípio do contraditório, sob pena de o Estado Constitucional Democrático regredir para tempos pretéritos e voltar aos atributos de Estado (impositivo) de Direito.

Assim, tal ordenamento jurídico global carece fazer frente a problemas diversos, tais como, conflitos de uniformidade e diferenças nacionais, a concorrência de normas global-nacional-locais, a atribuição de competências, a regulação do capital e nortes de governança global, a promoção dos direitos humanos, a preservação ambiental e os critérios de sustentabilidade planetária e o combate às redes criminosas; enfim, uma nova e eficaz forma de limitação de um poder de extrema fluidez, como é a ordem global atual. Eis o projeto a ser construído e executado...

\section{Referência}

CASSESE, Sabino. Il diritto globale: giustizia e democrazia oltre lo Stato. Torino: EINAUDI, 2009. (244p.) 
Maurizio Oliviero é Doutor em Direito Público pela Università di Roma "Tor Vergata" (Itália). Realizou curso de especialização em Direito Público pela Universidad de Alicante (Espanha); curso de especialização em Direito Público Econômico junto à Univerzita Karlova IV v Praze (República Tcheca); curso de especialização em Direito Parlamentar e Técnica de Legislação junto à Università degli Studi di Firenze em parceria com a Câmara dos Deputados (Itália); curso em Direito Comunitário no Istituto Guiridico della Repubblica di San Marino (São Marino). Professor Titular de Direito Público Comparado na Università degli Studi di Perugia (Itália), Professor Visiting na Columbia University - New York (EUA), Professor Visitante na Universidade do Vale do Itajaí (UNIVALI), Universidad de Alicante (Espanha), Al-Quds University of Jerusalem (Israel) e Üniversite Eskesir (Turquia).E-mail: oliviero@unipg.it.

Endereço profissional: Università degli Studi di Perugia. Facoltà di Giurisprudenza. Via Pascoli, 33. 06123. Perugia/Itália.

Márcio Ricardo Staffen é Doutorando em Direito Público Comparado pela Università degli Studi di Perugia (Itália), Doutorando e Mestre em Ciência Jurídica e Graduado em Direito pela Universidade do Vale do Itajaí (UNIVALI) Professor em cursos de Especialização da UNIVALI e Coordenador do Núcleo de Prática Jurídica do Centro Universitário para o Desenvolvimento do Alto Vale do Itajaí (UNIDAVI). Advogado. E-mail: staffen_sc@yahoo.com.br. Endereço profissional: Centro Universitário para o Desenvolvimento do Alto Vale do Itajaí. Rua Dr. Guilherme Gemballa, 13 - Caixa Postal 193. CEP: 89160932. Jardim América, Rio do Sul/SC. 